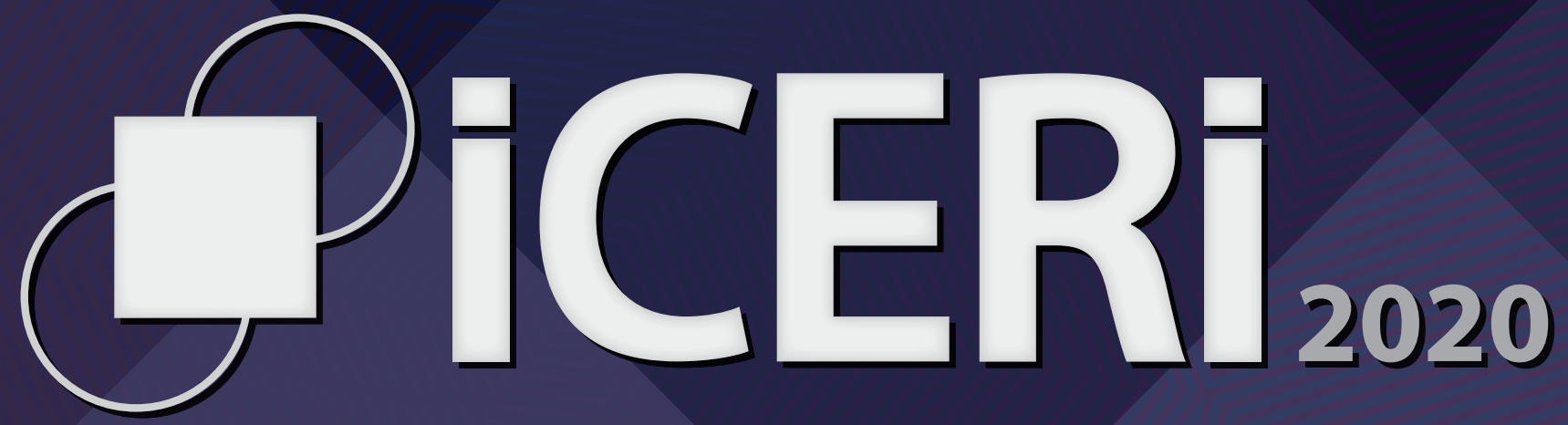

\title{
13TH INTERNATIONAL CONFERENCE OF EDUCATION, \\ RESEARCH AND INNOVATION
}

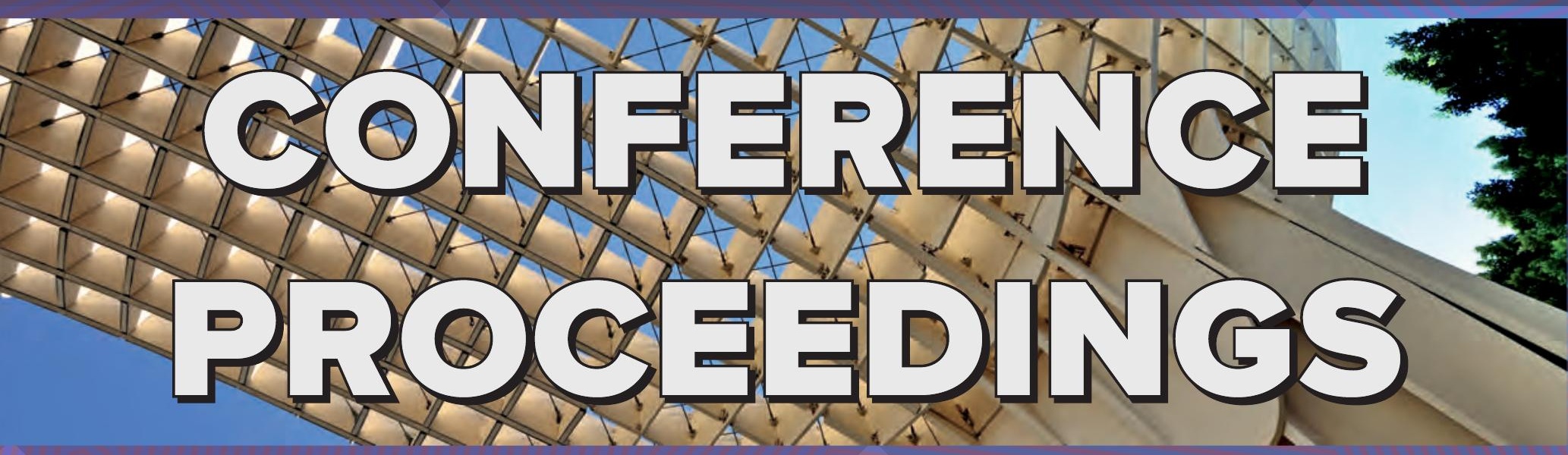

9-10 NOVEMBER 2020 iated.org/iceri 

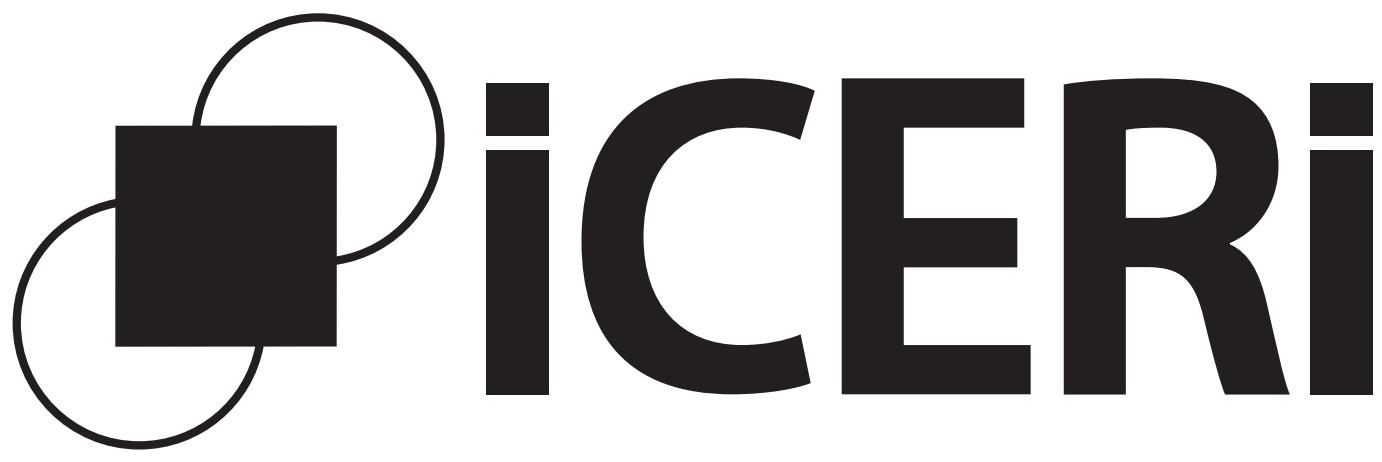

2020

13TH INTERNATIONAL CONFERENCE OF EDUCATION,

RESEARCH AND

INNOVATION
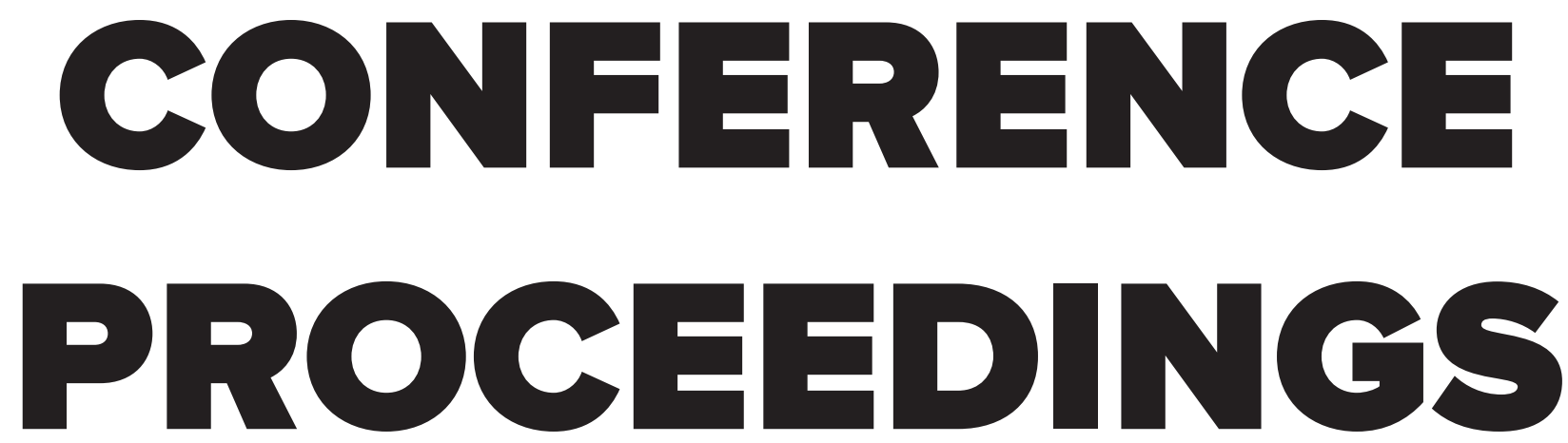

9-10 NOVEMBER 2020 iated.org/iceri 
Published by

IATED Academy

iated.org

\section{ICERI2020 Proceedings}

13th International Conference of Education, Research and Innovation

November 9th-10th, 2020

\section{Edited by}

L. Gómez Chova, A. López Martínez, I. Candel Torres

IATED Academy

ISBN: 978-84-09-24232-0

ISSN: 2340-1095

V- 2372-2020

Book cover designed by

J.L. Bernat

All rights reserved. Copyright (C) 2020, IATED

The papers published in these proceedings reflect the views only of the authors. The publisher cannot be held responsible for the validity or use of the information therein contained. 


\section{ICERI2020 COMMITTEE AND ADVISORY BOARD}

\author{
Achim Dannecker \\ Adriana Agnes Repellin-Moreno \\ Agustín López \\ Aileen Cotter \\ Akihiro Maeda \\ Alan Belcher \\ Alia Ammar \\ Amparo Girós \\ Ana Henriques \\ Ana Paula Lopes \\ Ana Tomás \\ Anna Romagnuolo \\ Annette Redmon \\ Antonio García \\ Breno Deffanti \\ Brian Garibaldi \\ Catherine O'Donnell \\ Chelo González \\ Christopher Evans \\ Christopher Mattatall \\ Craig Loewen \\ Craig Walker \\ Cynthia Rosas Magallanes \\ Dania Bilal \\ Daniel Abrahams \\ Darren Falconer \\ David Jennings \\ David Martí \\ Eladio Duque \\ Elmaziye Özgür \\ Ewa Bogacz-Wojtanowska \\ Fedor Duzhin \\ Fernando Enrique Ortiz Rodriguez \\ Fiachra Ó Súilleabháin \\ Filomena Soares \\ Francesco Galati \\ Frank Brosow \\ Helmut Woellik \\ Hiroyuki Obari \\ Ignacio Ballester \\ Ignacio Candel \\ Ineta Helmane \\ Iván Martínez \\ James Mackay \\ Jaroslaw Kujawski \\ Javier Domenech \\ Javier Martí \\ Jenny Eppard \\ Joanna Lees
}

\author{
SWITZERLAND Joanna Richardson \\ MEXICO João Monteiro \\ SPAIN John Craft \\ IRELAND Jose F. Cabeza \\ JAPAN Jose Luis Bernat \\ UNITED STATES Joseph Agbenyega \\ UNITED STATES Juanan Herrero \\ SPAIN Judith Szerdahelyi \\ PORTUGAL Kari Krell \\ PORTUGAL Kay Gallagher \\ SPAIN Laila Nordstrand Berg \\ ITALY Laurie Henry
}

UNITED STATES Lorena López

SPAIN Luis Gómez Chova

BRAZIL Luis Roseiro

UNITED STATES Luke Raeside

UNITED KINGDOM $M^{\underline{a}}$ Jesús Suesta

SPAIN Maria Porcel

UNITED KINGDOM Maria Rudneva

CANADA Martha Leal-Gonzalez

CANADA Matome Mashiapata

UNITED STATES Mayaugust Finkenberg

MEXICO Miguel Peiró

UNITED STATES Mike Hillis

UNITED STATES Murali Venkatesh

AUSTRALIA Norma Barrachina

IRELAND Orlando Belo

SPAIN Paul Fenn

SPAIN Paul Holland

CYPRUS Paul Hunter

POLAND Peter Gabor

SINGAPORE Peter Haber

MEXICO Pia Palotie

IRELAND Pirkko Pollari

PORTUGAL Richard Spencer

ITALY Rosa Cendros Araujo

GERMANY Salman Azhar

AUSTRIA Sérgio Luis Monteiro da Silva

JAPAN Sergio Pérez

SPAIN Sinead McCotter

SPAIN Sylvia Dempsey

LATVIA Taija Votkin

SPAIN Taketoshi Yokemura

NEW ZEALAND Tammy Ladwig

POLAND Thomas Lavery

SPAIN Victoria Kompanets

SPAIN Wendy Gorton

UNITED ARAB EMIRATES Xavier Lefranc

FRANCE Xema Pedrós
UNITED KINGDOM

PORTUGAL

UNITED STATES

SPAIN

SPAIN

UNITED ARAB EMIRATES

SPAIN

UNITED STATES

CANADA

UNITED ARAB EMIRATES

NORWAY

UNITED STATES

SPAIN

SPAIN

PORTUGAL

IRELAND

SPAIN

SPAIN

RUSSIAN FEDERATION

MEXICO

SOUTH AFRICA

UNITED STATES

SPAIN

UNITED STATES

UNITED STATES

SPAIN

PORTUGAL

UNITED KINGDOM

UNITED KINGDOM

SWITZERLAND

CANADA

AUSTRIA

FINLAND

FINLAND

UNITED KINGDOM

CANADA

UNITED STATES

BRAZIL

SPAIN

UNITED KINGDOM

IRELAND

FINLAND

JAPAN

UNITED STATES

UNITED KINGDOM

FINLAND

UNITED STATES

FRANCE

SPAIN 


\section{CONFERENCE TRACKS \& SESSIONS}

\section{INNOVATIVE EDUCATIONAL TECHNOLOGIES}

Technology Enhanced Learning

Virtual \& Augmented Reality

Research on Educational Technologies

Coding \& Educational Robots

\section{DIGITAL TRANSFORMATION OF EDUCATION}

Data Science \& AI in Education

Learning Analytics

Digital Technologies and Resources for Learning under Lockdown

21st Century Skills

\section{DIGITAL \& DISTANCE LEARNING}

Distance Education in COVID-19 Times

MOOCs \& OERs

Blended \& Mobile Learning

e-Learning

LMS \& VLES

\section{ACTIVE \& STUDENT-CENTERED LEARNING}

Gamification \& Game-based Learning

Active \& Experiential Learning

Problem \& Project-Based Learning

Pedagogical Innovations

Soft Skills Development

\section{ASSESSMENT, MENTORING \& STUDENT SUPPORT}

Assessment \& Evaluation

Rethinking Assessment in COVID-19 Times

Mentoring \& Tutoring

Student Engagement \& Wellbeing in COVID-19 Times

Student Support \& Motivation

\section{INCLUSION \& MULTICULTURALITY}

Inclusive Education

Special Educational Needs

Multicultural Education

Inclusion and Equity to Minimize the Educational Disruption during COVID-19

Diversity Issues 


\section{EDUCATIONAL STAGES AND LIFE-LONG LEARNING}

From Pre-school to Secondary Education

Higher Education \& Transition to the Job Market

Vocational Training

Exchange Programmes \& International Experiences

Developing Entrepreneurship in Education

Life-Long \& Workplace Learning

\section{QUALITY \& IMPACTS OF EDUCATION}

Quality in Education

Curriculum Design Experiences

Sustainability \& Environmental Awareness

Social Impact of Education

University-Industry Collaboration

Educational Policies \& Internationalization

\section{TEACHER TRAINING \& ED. MANAGEMENT}

ICT \& Digital Skills

Teacher Training and Support in COVID-19 Times

Professional Development of Teachers

Educational Management

\section{STEM EDUCATION}

Maths \& Statistics

Engineering Education

STEM Experiences

Computer Science Education

\section{LANGUAGE LEARNING AND TEACHING}

Foreign Languages

Language Learning

Technology for Language Learning

\section{DISCIPLINE-ORIENTED SESSIONS}

Architecture \& Civil Engineering Education

Health Sciences Education

Business \& Accounting Education

Social Work Education 


\section{ABOUT ICERI2020 Proceedings}

\section{HTML Interface: Navigating with the Web browser}

This USB Flash drive includes all presented papers at ICERI2020 conference. It has been formatted similarly to the conference Web site in order to keep a familiar environment and to provide access to the papers trough your default Web browser (open the file named "ICERI2020_Proceedings.html").

An Author Index, a Session Index, and the Technical Program are included in HTML format to aid you in finding conference papers. Using these HTML files as a starting point, you can access other useful information related to the conference.

The links in the Session List jump to the corresponding location in the Technical Program. The links in the Technical Program and the Author Index open the selected paper in a new window. These links are located on the titles of the papers and the Technical Program or Author Index window remains open.

\section{Full Text Search: Searching ICERI2020 index file of cataloged PDFs}

If you have Adobe Acrobat Reader version 6 or later (www.adobe.com), you can perform a full-text search for terms found in ICERI2020 proceedings papers.

Important: To search the PDF index, you must open Acrobat as a stand-alone application, not within your web browser, i.e. you should open directly the file "ICERI2020_FrontMatter.pdf" with your Adobe Acrobat or Acrobat Reader application.

This PDF file is attached to an Adobe PDF index that allows text search in all PDF papers by using the Acrobat search tool (not the same as the find tool). The full-text index is an alphabetized list of all the words used in the collection of conference papers. Searching an index is much faster than searching all the text in the documents.

To search the ICERI2020 Proceedings index:

1. Open the Search PDF pane through the menu "Edit $>$ Advanced Search" or click in the PDF bookmark titled "SEARCH PAPERS CONTENT".

2. The "ICERI2020_index.pdx" should be the currently selected index in the Search window (if the index is not listed, click Add, locate the index file .pdx, and then click Open).

3. Type the search text, click Search button, and then proceed with your query.

For Acrobat 9 and later:

1. In the "Edit" menu, choose "Search". You may receive a message from Acrobat asking if it is safe to load the Catalog Index. Click "Load".

2. A new window will appear with search options. Enter your search terms and proceed with your search as usual.

For Acrobat 8:

1. Open the Search window, type the words you want to find, and then click Use Advanced Search Options (near the bottom of the window).

2. For Look In, choose Select Index.

3. In the Index Selection dialog box, select an index, if the one you want to search is available, or click Add and then locate and select the index to be searched, and click Open. Repeat as needed until all the indexes you want to search are selected.

4. Click OK to close the Index Selection dialog box, and then choose Currently Selected Indexes on the Look In pop-up menu.

5. Proceed with your search as usual, selecting other options you want to apply, and click Search.

For Acrobat 7 and earlier:

1. In the "Edit" menu, choose "Full Text Search".

2. A new window will appear with search options. Enter your search terms and proceed with your search as usual. 


\title{
PEDAGOGICAL CHALLENGES IN TIMES OF SARS-COV-2 IN EARLY CHILDHOOD EDUCATION
}

\author{
C. Mesquita' ${ }^{1}$, R.P. Lopes ${ }^{2}$, A.C. Loureiro ${ }^{1}$, C. Ribeiro' 1 \\ ${ }^{1}$ Research Center in Basic Education, Polytechnic Institute of Bragança (PORTUGAL) \\ ${ }^{2}$ Research Center in Digitalization and Intelligent Robotics, Instituto Politécnico de Bragança \\ (PORTUGAL)
}

\begin{abstract}
As a strategy to contain the new coronavirus transmission, educational institutions in more than 100 countries were closed since March 2020. Facing lockdown, schools sought to reorganize their operation, preparing remote activities, using platforms and other means of communication considering the need to ensure, as much as possible, the learning of children and young people. The study described in this paper resulted from the need to understand the mechanisms created by institutional leaders and childhood educators, among others, to cope with this unexpected situation. This research also aims to understand the feelings, constraints and opportunities experienced by Portuguese educators, as well as the strategies and actions developed in order to be able to provide support to children and their families. This study also documents the impact that this particular situation had on the creation of online educational offer, on the answers found by the official entities, as well as on the practices and conceptions of educators. This is a research conducted with childhood educators during the first semester of 2020, a period in which educational institutions came across the guidelines to "close the doors" and the need to continue promoting children's educational activities. Methodologically, the study assumes a qualitative approach, in order to assess the feelings, experiences and perceptions of the actors who experienced the situation. For data collection, two Focus Groups were developed, involving 20 educators and guided by a pre-structured script that comprised seven blocks of questions. The Focus Groups were recorded and, subsequently, transcribed and submitted to content analysis, whose heuristic function increases the propensity of the discovery of the reality experienced by the actors. From the content analysis, categories emerged that allowed the analysis of the discourses. The text produced was analysed and described in an articulated way, trying to apprehend the specific conditions in which it was conceived, revealing a certain order of reality, from which the narrative was made. Data analysis reveals that the majority of the pedagogical coordination of the institutions provided recommendations for remote work. Some educators indicated that they had recommendations for work from home in non-face-to-face contact, but others, through the pedagogical coordination, suggested the platforms they should use, the type of work they should do and how often they should contact children. The data highlight the efforts of some professionals to maintain contact with children. The educators are aware of the effort that families and children made during this period and reveal that this situation was more difficult for children in vulnerable situations.
\end{abstract}

Keywords: Early Childhood Education; remote activities; pedagogical challenges.

\section{THE USE TECHNOLOGIES BY THE TEACHERS}

Nowadays it is unthinkable to ignore the influences that Information and Communication Technologies (ICT) have on children born in a digital age. Educating with technologies is unavoidable, both in the family environment and in educational environments. In the pre-school education environment, the use of technologies is beginning to be an increasingly recognized reality. In fact, the potential of information and communication technologies, with regard to their use, the possibilities of access to information, digital resources, which add value in almost all sectors of society, to their omnipresence, increasingly marked in our daily life, it is difficult to ignore the contributions of ICT in enriching learning contexts [1], [2]. Today, there is a wide variety of digital technologies available on the web, accessible, interactive, collaborative and that can be used to learn in both face-to-face and online environments. According to Moran [3], technologies make it possible to work with diverse activities thanks to "mobility and virtualization that free us from rigid, predictable, determined spaces and times" (p. 89). As the author points out, all these potentialities of the use of technologies are possible because: 
The most interesting technologies are now integrated into smartphones, mobile phones connected to the Internet. They are in the hands of many managers, teachers, students and families. Mobile phones, tablets and notebooks help us access the information we need, develop projects, talk in various ways, share our knowledge, ask questions, participate in discussions, speak in public, write better [3, p. 98].

However, using ICT in educational contexts requires a minimum of technological and digital skills and an adequacy of education and education processes, very focused on the autonomy and self-learning of children and young people. In addition, technologies must be inserted in a pedagogical context capable of forming responsible, ethical, critical and supportive citizens in the face of today's society [4]-[6]. in this context, the changes that are pressing relate to a change in attitude towards knowledge and learning. This implies that teachers and students will have different roles to develop, as well as the classroom environment and educational practices within it [6]. The use of technologies as an educational means leads to a questioning of the role of the school and the role of the teacher. According to Moran [3], the true function of the school should not be to teach, but to create learning conditions. The teacher should not worry about transmitting knowledge, since information is available on the internet abundantly, but rather to worry about creating innovative learning environments and guiding the process of intellectual development of the student.

The current pandemic context of COVID-19 brings out the need to control the advance and dissemination of contagion, which has led health authorities to advise against meetings and face-toface sessions, for example, in educational and educational institutions. Schools have had to adapt in view of the need to ensure the learning of children and young people. This readaptation led to forms of non-face-to-face contact, using technological devices that enhance distance learning. This situation has brought many challenges to the educational sector, on the part of teachers regarding the preparation for distance work and digital competence, by educational institutions in relation to technological and pedagogical preparation for non-face-to-face teaching, by children who found themselves outside the environment and educational interaction and, on the part of parents, who found themselves at home with their telework added to the daily educational attention to their children.

Given this context, considering the diversity of realities that preschool education institutions present, this study aims to know how childhood educators professionally experienced the period of physical confinement and what strategies the institutions used to overcome the difficulties caused by the epidemic situation. More specifically, we want to know how early childhood educators have established distance interactions with children in order to promote their learning.

There are already some evidences in scientific literature on the use of technologies by educational agents. Some analyze the educational practices of childhood educators and teachers at different levels of education, investigating whether they use technologies, how they do so and what their difficulties are, crossing the data with their conceptions. Some studies indicate that, although children are interested in technologies, their use is reduced in the classroom by educators and teachers [7]. On the other hand, other studies reveal that teachers use technologies and recognize their importance [8]-[11] but, after the analysis of their educational practices, traditionalist, transmissive, non-reflective and non-critical use is found [9],[10], [12].

The lack of proper teacher training on technologies in also referred as one major problem in the pedagogical use of ICT tools, stating that most teachers and educators use them after self-knowledge, self-discovery and self-training [8], [13]. From the point of view of Santos, Castelano and Almeida [14] even when schools offer teacher training courses, they do not arouse much interest in doing so, frequently abandoning the effort. Another contribution pointed out by these researchers is the fact that many teachers have difficulties in using didactics and effectively technologies in their educational practices, even after participating in training.

With regard to the technological resources that teachers use, the data vary according to the research. In the study by Folho, Santos and Abar [10] we observed evidence that ICT is used only as an additional resource for consulting magazines, newspapers and digital books, sending e-mail messages, searching the internet, presenting movies and consulting blogs. In the same way, Rub [11], in an investigation with educators and teachers of the 1st cycle of basic education, obtained data that revealed that the used of technologies is mainly reduced to create presentations, tests and evaluation exams.

The conceptions that teachers have about their role in the classroom influence and even define the use that they make of technologies in an educational context. As Palak and Walls [15] have proven, teachers who use teaching methodologies focused on the transmissive, traditionalist and content 
exhibition model, not recognizing the value of technologies beyond that. Conversely, in the studies conducted by Bergmann and Sams [16] and Bacich and Moran [6] it is evident that teachers who use more active didactic-pedagogical methodologies perceive the potential that ICT has for the learning process of the child/student. It is important to emphasize that the use of technologies as an educational means proposes a rethink about the role of the school, the role of the teacher and the student who intends to graduate.

A current study focused on the impact of COVID-19 on preschool education, more specifically on the strategies developed by both institutions and childhood educators demonstrated relevant data. During the period of isolation, and with a recommendation for remote work, childhood educators used various platforms and/or resources to keep in touch with children and their families, either on their own initiative, or on the recommendation of the institutions. The study also reveals that some professionals had difficulty in establishing contact with children and families because they did not have the mastery of educational technologies. It was also found that some families did not observe technological conditions that allowed them to contact the school digitally. In the study it is revealed that educators found some solutions to this problem, using the post or even by direct contact with families in the delivery of materials [17].

According to Meirinhos and Osório [18] it is necessary to transform the school in order to meet the demands of the knowledge society as much as it is necessary to rethink the training of educators/teachers, making them up-to-date professionals and prepared to propose educational innovations. According to this conception, Loureiro, Cavalcanti and Tavares [19], reveal that models of teacher training based on active methodologies "is an effective way to enable them to experience learning experiences that can then be transposed to the contexts where they act as educators" ( $p$. 471). The authors suggest that the practice of allowing teachers to experience moments of action and reflection, during initial and/or continuous training, enables the training of reflective professionals, who is more available to develop active methodologies in the educational contexts where they work. Also according to Meirinhos and Osório [18], the limited use of ICT in the school context, by educators/teachers, weakens the use of alternative forms in practices in order to result in significant improvements in the learning of children/students. Thus, incorporating new technologies, without combining them with participatory models, will not result in educational improvements. The creation of learning-friendly environments, where children/students participate and are active builders in learning, implies the re-creation of pedagogy based on the ethics of respect, which promotes the autonomy of the person in training [20].

This perspective inspired the present study, which focuses on pre-school education and which, considering this particular moment, caused by COVID-19.

\section{METHODOLOGY}

This study resulted from the need to understand the mechanisms that were created by various actors, institutional leaders and childhood educators, to face this situation caused by the COVID-19 pandemic. It also intends to understand the feelings, constraints and opportunities experienced by Portuguese educators, as well as about the strategies and actions they have developed to support children and their families. This is a research conducted with childhood educators during the first half of 2020, a period in which educational institutions came across guidelines to "close the doors" and the need to continue promoting children's educational activities. Methodologically, the study takes a qualitative approach, in order to access the feelings, experiences and perceptions of the actors who experienced the situation, using the techniques, instrument of data collection and analysis that are explained in the following subsections.

\subsection{Data collection and analysis techniques and tools}

The choice of data collection technique fell on the focus group. The ontology inherent to the concept of focus group, expressed in this work, assumes the dialogical nature that highlights that individual and collective identities are constructed through professional habitus [21]. These constructions help expand the horizons of experience and meaning. It is understood in this sense that practices and meanings are in relation to the contexts in which they occur and according to the principles of the hermeneutic circle, in which it comprises parts of phenomena (text, person, event, culture) always involves the understanding of the total phenomenon [22]. 
For the collection of data from the educators' conceptions, two focus groups were developed, through the Zoom platform, guided by a pre-structured script that comprised three blocks of questions: difficulties encountered; guarantee of the rights of the child; learning carried out. A total of 20 childhood educators were involved in this procedure.

\subsection{Characterization of participants}

Participants were chosen for their availability and ease of participating in the focus group. To identify the participants, they were asked to fill out a form that was sent via Google Forms.

All participants are female, out of a total of 20 kindergarten teachers. Of these, eight are between 41 and 50 years old, ten are aged between 31 and 40 years and 51 to 60 years old, who observe five participants in each. Two childhood educators over 60 years of age also participated.

The participants included 10 childhood educators with bachelor's degree, 9 with a master's degree and 1 with specialization. Their time service varies between 0 and 10 years (six participants), 11 and 20 years (six participants), 31 and 40 years (five participants), 21 and 30 years (two participants), and more than 40 years (one participant). The childhood educators participating in this study perform their functions in public institutions (eleven childhood educators), in private institutions of social solidarity (seven participants) and in a private institution (2 participants). Regarding the ages of the children with which they work, it is observed that most work with mixed groups with children aged 3,4 and 5 years (14 participants), with four participants working with children of 1 year, one with a group of 2 years and another with a group of 5 years.

\subsection{Data analysis techniques}

The focus groups were recorded and transcribed. Finally, content analysis was carried out, whose heuristic function increases the propensity to discover the reality underlying the collected productions [23].

The emerging categories were organized in grids. The discourse analysis considered the specific conditions in which it was produced, corresponding to a certain order of reality. The data were placed in a new context that we built, based on the objectives of our study. We did not only cut out units of the text, but we tried to make sense of them, contextualizing them. Each judgment about the meaning of a unit of registration and context constitutes an inference.

At first, the codification and categorization were interpretive, having been rethought and reflected in subsequent moments, analyzing its completeness and exclusivity [24]. The recording units were distributed by categories and subcategories, according to analog regroups. For the coding of the categories, letters in alphabetical order were used accompanied by a number (A1, A2, B1, C1...) and in the subcategories, the letters and numbers of the categories, accompanied by another number (A1.1, A1.2, A2.1...). The voices of the interviewees are presented in an alphanumeric code the letters indicate El, indicate Childhood Educator and the digits their differentiation. From this analysis, six categories and thirty-seven subcategories emerged that present and explain in the subsection results.

\section{RESULTS}

Reading the data resulted in the definition of the following categories: (i) Difficulties experienced by professionals, (ii) Perceived difficulties in children, (iii) Perceived difficulties in parents, (iv) Guarantee of the children's rights, (v) Emerged learning, (vi) Consequences of the pandemic. The data will be read interpretatively, based on the participants' discourses.

\subsection{Difficulties experienced by professionals}

In this category (A1 - Difficulties felt by the professionals) ten subcategories emerged: (A1.1) Difficulties in articulating personal life with work; (A1.2) Difficulties in the management of educational action; (A1.3) Difficulty in reaching all children and families, (A1.4) Discontent and Disorientation towards the strategies to be developed (A1.5) Increase in working hours; (A1.6) Difficulties of the psychological fora; (A1.7) Difficulties in the use of technologies; (A1.8) Difficulty in the family's adhering; (A1.9) The assumption of other functions and; (A1.10) Coordination difficulties.

The analysis of the answers found that educators have greater difficulty in time management, with regard to the subcategory "Difficulties in articulating personal life with work" (A1.1). Of the 20 
educators, all in some way, they expressed difficulties in managing work at home due to several factors expressed in the following statements:

"Coordinating family management, work, pay attention to my daughter, etc." El1

"lack of family time and personal time, too much time in front of screens" EI5

"Find compatible schedules for all [family members] at the same time and network quality" El7

"Time management, because I have two children" El8

"Time! To run my daughter's school, and prepare my boys' activities, was not an easy task." El17

One of the greatest difficulties of a non-face-to-face interaction pointed out by the educators is the "management of the educational action", which they consider not to be as effective in distance education modalities, with regard to children in this age group, as was well expressed by educator El9: "I felt that working with children of these ages at a distance, despite maintaining the affective bond with each one, harms the essential of our daily lives". The expression of El9 reflects the pedagogical training and the design of pre-school education to be an educational action created for the face-to-face modality. It is possible to verify this finding in the statement expressed by the educator EI20

"The absence of direct work implied the reduction of gains in relation to affective development, generally compromising the whole development of the child with their learning, exchanges of knowledge in the group, presentations of productions to the large group, articulation between groups, etc."

We noticed, from the statements of the educators, that the participation of families and children was a great challenge in this process, either due to lack of involvement, or by difficulties in the access to the Internet and access to adequate infrastructure. This statement is based on the data collected in subcategories A1.3 and A1.8. We noticed that the difficulties were very close to the technological conditions of these students, which left educators with great concern, as well as the educators "However, I need to know about those children and be able to accompany them". El1; "Reach all children/families in a way accessible to all" El2. It is perceived that the difficulties of access to children, associated with difficulties in managing the educational action, were intensified by "Discontent and Disorientation towards the strategies to be developed" (A1.4) and the "Increase in working hours" (A1.5), added to the difficulties in having to assume other functions than thatof educator (A1.9). Overall, all educators expressed a failure to communicate "management of educational professionals" and "lack of professional recognition" as the most relevant points of disappointment and disorientation, and by the "lack of means of communication with parents" due to the increase in workload. These statements are well expressed in the following speeches:

"Failure to communicate the concepts and criteria of the rules created by the Pedagogical Direction in relation to different teachers, lack of professional recognition by the Board during quarantine." E/3

"Lack of guidance and leadership on the part of the direction of the grouping of schools to which I belong." E/2

"Communication with the Management on changes to the labour regime, lack of information and negotiation of reopening rules." El10

"layoff imposition rather than telework." El10 and E13

"lack of institutional means for communication with parents." El13

"Do many more hours of work to get to all families and children with their needs and specificity." El12

Among the other subcategories of the category "A1: Difficulties Felt by professionals", it is important to highlight the difficulties in the use of technologies (A1.7). It was found that educators had no knowledge of the implications and possibilities of using ICT for the planning of online activities. When asked about the use of technological resources, all (20) stated that they had difficulties in use and that they were forced to learn new technologies in record time. This reinforces the emergence of teacher training for digital skills, preparing them for the effective integration of ICT into daily activities, understanding the implications and possibilities of using them in educational contexts. 
Regarding the "psychological difficulties" (A1.6), three participants reported changes in their emotional health, all related to the social aspect, as expressed in the statements "I started to have frequent insomnia, nightmares, constant anxiety". El2; "The isolation, the lack of affections, the lack of being with the group and the adults I work with." El11; "Lack of personal contact." El19.

Only one participant, performing coordination functions, reported having difficulties in managing the educational professionals. We can draw an analogy between this statement and the educators' statement about dissatisfaction and disorientation towards the strategies to be developed. We conclude that both difficulties permeate a common problem: the lack of effective and dialogical communication among all educational agents.

\subsection{Perceived Difficulties in Children}

The Perceived Difficulties in Children (A2) verbalized by the educators were structured in five subcategories: (A2.1) The Lack of interaction; (A2.2) The lack of freedom; (A2.3) Setback in autonomy; (A2: 4) Lack of motivation and; (A2:5) Difficulty concentrating.

Regarding the difficulties that the educators perceived in the children, some express the lack of affections, explicit in the following verbalizations: "Sometimes some children were having difficulty performing a task autonomously and felt frustration and I had a lot of difficulty in being able to comfort the child by the lack of touch, which I am used to" (EI1) and "The lack of touch (the virtual relationship is very abstract for them) but we managed to maintain a relationship (with a lot of personal investment)" (EI5). This consequence also affected the educators, who were forced to seek solutions to comfort the children.

The lack of freedom was also mentioned through verbalizations: "I felt that the children did not understand very well what happened and felt a little abandoned and that all their freedom was taken away from them" (EI18) and "Lack of freedom to move freely and make a normal life (I have an example of several children who did not leave home during the two and a half months)" (El11). The statements of the educators show that the impediment to leaving the house left the children confused and with the feeling that they were given freedom.

Another visible obstacle, identified only after some time of remote work, was the lack of motivation. If enthusiasm initially prevailed, it dissipated over time, leading to an impact on participation: "At first they were excited about this new methodology, but after a few weeks I felt that some children were disinterested and less participative" (EI3). An educator points to excessive activities (which have become routine) as a possible cause: "I also felt, in the midst of this quarantine, a demotivation of the kids. In my institution there were many sessions a week (10) and when it began to fall into routine some children began to become disinterested. Then they eventually recovered" (El1). Tiredness is also referred to as a possible reason "At the beginning there was interest in novelty, then over the weeks tiredness" (EI5). According to El4 this led to some children wanting to stop participating in the activities.

The lack of concentration is expressed as a problem felt: "In online meetings it was difficult to keep them focused and attentive to my interventions and dynamics" (El19). This confinement led to a difficulty that can also be interpreted as a consequence, the regression in autonomy, perception pointed out by El20.

\subsection{Perceived difficulties in parents}

In the category Perceived difficulties in parents (A3), the following subcategories emerged: (A3.1) Difficulties with technologies; (A3.2) difficulty in adhering to the proposals and responding; (A3.3) Difficulties in articulating personal life with work and; (A3.4) Distress in the difficulty of support.

The educators, regarding the difficulties they noticed in the parents, pointed out a diversity of aspects. They reported that the parents did not have access to technological resources: "insecurity that this confinement created as well as the lack of support at home at the computer level." (El11).

The subcategory, with the highest incidence rate in the educators' discourses, was the difficulty of articulation between personal life and work. Some parents were in telework, which did not allow them to have all the time available with their children. This situation was the most visible in parents with more than one child, where the greatest follow-up fell on those who attended compulsory education levels, as we can see in the following statements: "Management of work with the children's online school and with the fact of having a child at home." (EI1); "Reconciling work and telework with the 
requests of children and school, being parents of more than one child, be a priority to support older children and not have time for younger children." (EI2). This lack of time combined with the whole context and situation lived created an anguish in the difficulty of support, visible in the verbalization: "Most [of the parents] were in telework and the lack of knowing how to deal with the emotional issues that were arising, getting very anxious, because the children did not want to do the activities and this for them made them very frustrated, although I told them that it was normal and to talk to their children, respecting their time and their will" (El18).

Visible through the speech of El19 we can inet another difficulty, the acceptance of the proposals and in giving answers. The lack of parents' training and lack of routines is visible by their verbalization: "Difficulties in putting into practice the suggestions of activities I have been sending due to lack of availability and difficulty in putting into practice appropriate strategies to enable the activities and some difficulties in maintaining the daily routines of children in adequate periods of time (e.g. Standing meals, short nap, trips to bed later, etc.)."

\subsection{Guarantee of the children's rights}

The category "Guarantee of the children's rights" (B1) resulted from a rich and complex discussion, grouped into a diverse range of subcategories: (B1.2) Commitment to the Right to Participate; (B1.3) Deprivation of the right of affection; (B1.4) Commitment of the socializing process; (B1.5) Worsening of social inequalities; (B1.6) Right to learn; (B1.7) Effort to guarantee all rights; (B1.8) Constraints on fundamental rights caused by social and educational agents; (B1.9) Increased quality of family time and; (B1.10) Deprivation of the right to play.

The verbalizations suggest two profiles of childhood educators: some that integrate in a more positive line and others that attribute to this confinement time a more negative view.

Some educators consider that there was an effort to guarantee all rights, even mentioning "I do not believe it was disrespectful. I feel it was something new for everyone, but I know that everyone I contacted with has worked hard to continue to give the best to the children, within the limits that we have been allowed." (EI9). In this more positivist line, there are educators who look at this phase taking into account the increased quality of family time. The educators emphasize that some children have lived "very enriching experiences that they will remember for life" (El16) and had "a unique opportunity to create affective bonds and spend time with parents and siblings that would otherwise never happen" (EI15). Still within this group, we observed educators who consider that children's rights were safeguarded, as expressed in the following verbalization:

"In my context, given the demand for the situation, I think the direct ones were assured, because all the children were able to be with the families and they all had a backyard or garden where they could continue to farm. In fact, the children have come back very well, in terms of development, because the parents are imbued are aligned with our educational philosophy (Forest, Waldorf, Montessori and Reggio Emilia) and have continued at home, without the need for planning activities or tasks." (El17)

Among the educators with a more pessimistic view of the situation, a variety of consequences and rights of children who, in their opinions, have been violated, are mentioned. There are educators who express the worsening of social inequalities, reflecting the impact of this isolation on the most disadvantaged children: "children who were already in precarious situations worsened" (EI18); "Certainly in many families, and especially in the most disadvantaged, children's rights will not have been guaranteed or respected" (El2); "[Did increase] ... situations of hunger, violence, abuse and mistreatment that worsened during this period" (EI16). It is mentioned the commitment of the right of protection, essentially focused on the hours that children were forced to spend in front of the screens: "Exposure to screens is also not ideal for these children and we know that given the situation in which the parents were, they also felt the need to expose them more to screens beyond that promoted by us" (El1). The commitment of the right to participate was also indicated, pointing out that the children's voice was not taken into account: "the children had no chance to speak about this whole situation" (El15).

Some educators consider that there has been a deprivation of the right of affection that has become more visible with the return to institutions and with the defined protection rules: "The fact of preventing toy-sharing among children and avoiding physical proximity, at the moment, we are devaluing the sharing and affections so important for the healthy development of children in these age groups" (El15). This deprivation is also reflected on the commitment of the socializing process, as 
demonstrated in the following verbalizations: "The interruption of peer-to-peer socialization, poorly managed prolonged confinement and the exercise of parents' authority were constraints to fundamental rights" (EI10); "It is unnatural to work with young children at a distance, without the social component (so important), without affections, without the interaction of fundamental dialogues for the cooperative construction of knowledge." (EI19). One educator mentioned a flaw in the right to learn.

Even after returning to kindergarten, some educators consider that children's rights are not being fulfilled, and that there are constraints on fundamental rights caused by social and educational agents. They point to severe criticism of government regulations and institutions, even stating that "In general groupings, the rights of children are not respecting or complying with the OCEPE" (EI20). Focusing on the deprivation of the right to play, an educator says that even now after returning "many educators and directors of groupings, continue to deprive children of playing and to join even if they are in the presence of other children inside the kindergarten" (EI20).

\subsection{Emerged Learning}

With regard to the category Emerged Learning (C1) the discourses of the educators are part of the following subcategories: (C1.1) Recognition of the capacity to adapt; (C1.2) Give value to life and affections; (C1.3) The importance of interaction and face-to-face learning; (C1.4) Use of Technology; (C1.5) Recognize the family contribution; (C1.6) Recognize the unpredictability of life; (C1.7) Get to know children better.

It is said that educators perceive the ability to adapt as an apprenticeship, referring both to their personal adaptation and to the children's ability to adapt. The following comments stood out:

"Children show us how human beings are an animal that can adapt and be happy in the most varied conditions. I had more time for myself and to reflect on the difficulties that the parents had and, in this sense, through videos I was able to give suggestions for support." (E/9)

"I have learned that our ability to adapt is enormous and that people who do not enjoy it are greatly impairing the development of children." (EI20)

The statements of the educators show that the quarantine period shook and affected everyone and is also a moment of reflection for the present and for the future, personally and professionally. It made people value health and the little things in life, such as affection, freedom and social contact.

"The greatest thing I learn from this situation is that although human relationships are complex, affections, coexistence and love are fundamental in people's lives. I have learned to value health, freedom, work, the family, which we do not value in a regular situation, and that we now realize how important they are in our lives. (El14)

"We must recognize the value of personal contacts. the value of the hug, cuddle, the kiss and the little treats. We never thought about how important this was." (El19)

Data analysis showed that the educators reflected and came to the conclusion that the type of learning that a kindergarten promotes, with the appreciation of contact and interaction with the other, only makes sense if it is face-to-face. It is also observed that this reflection provided the rediscovery of professional pleasure by some educators:

"The greatest lesson I took from this time was that it is not possible to work all the contents without what the kindergarten room can provide to a child: sharing affections, toys, playing games, interactions with peers and other adults. Kindergarten only makes sense in face-to-face interaction. I also learned that... I still really like being in the room with a group of kids, that's the only way it makes sense!" (EI3)

The use of technologies was another factor recognized as an apprenticeship. The following discourses express that the educators have learned to use some digital platforms, feeling more capable and prepared for the future (EI4) taking advantage of the future of this learning by mentioning that the "newdigital platforms can be a good tool in the future, enablingcloser and faster communication with families" (EI9).

Another subcategory was the recognition of the contribution of the children's family. Educators point out and value the parents' efforts to carry out the plans that were suggested to them, ensuring that the children continue to develop and learn. The following sentence characterizes this situation: "Parents 
were a main driver in that. Children had individual support at home with positive reinforcements and their holistic development was manifestly positive and enriching." (El11).

An educator mentions that this period allowed her to know her children better, discovering in these, unknown facets.

\subsection{Consequences of the pandemic}

In the category Pandemic consequence (C2) the following subcategories emerged: (C2.1) Problems in the development of children; (C2.1) Family Problems (socio-economic). With regard to the development of children, some educators see the work carried out as a "patch" that "has caused serious harm to the holistic development of the child." (El16). It is also emphasized, as already stated when referring to the perceived difficulties in parents, that the pandemic situation "had serious family and adult problems. Not to mention the lack of money and professional difficulties." (El16).

\section{CONCLUSIONS}

This investigation reflects on the strategies, restrictions and feelings experienced by early childhood educators in quarantine period, during the lock down of kindergartens and the cancellation of face-toface activities, due to SARS-COV-2.

The study was based on interpretative analysis that resulted in the development of a categorial system. This process resulted from the discourse of 20 educators collected in two Focus Group. The participants were all female, from different points of Portugal. The analysis allows us to perceive two profiles of different childhood educators, one truly positivist, who look at the quarantine period as an enriching time, pointing out advantages at the social level, greater proximity to the family, valuing the small things of life (affections, freedom, embrace, etc.), but also at the level of learning, referring to their discoveries in the world of technologies. On the other hand, we have a group of more negativist educators, who look at this situation as authentic violations of children's rights, pointing criticism to the institutions where they work and to all government institutions, pointing out flaws in the defined measures.

With regard to the guarantee of children's rights, it seems clear that the majority of the participating educators consider that there has been a clear violation of the right to affection and play. Regarding the right of protection, some educators suggested that this situation may put at risk some children in situations of greater vulnerability, and this should be prevented in similar crisis situations. It is also evident that it among families in social and economic difficulties that the consequences of the pandemic have been felt the most. The child's right of participation was truly compromised, since they were never called to express their opinion, nor were ever heard by social agents, about how to return to kindergarten and on the work to be done.

The greatest difficulty that the educators felt coincides with the one they observed in the parents, referring to the reconciliation between personal and professional life. This period required them to be professionals in their activity, teachers of children and full-time parents, worsen in families with more than one child.

\section{ACKNOWLEDGEMENTS}

This work has been supported by FCT - Fundação para a Ciência e Tecnologia within the Project Scope: UIDB/05777/2020.

\section{REFERENCES}

[1] L. Amante, 'Infância, escola e novas tecnologias', in As TIC na educação em Portugal: conceções e práticas, F. Costa, H. Peralta, and S. Viseu, Eds. Porto: Porto Editora, 2007, pp. 102-123.

[2] Miranda-Pinto and Osório, 'Kids Media Lab: Tecnologias e a Aprendizagem da Programação em Idade Pré-escolar', in Atas do XVII Simpósio Internacional de Informática Educativa, SIIE15, M. R. Rodrigues, M. L. Nistal, and M. Figueiredo, Eds. 2015.

[3] J. Moran, 'Mudando a educação com metodologias ativas', in Convergências Midiáticas, Educação e Cidadania: aproximações jovens, C. A. Souza and O. E. T. Morales, Eds. Ponta Grossa: UEPG/PROEX, 2015, pp. 15-33. 
[4] M. E. B. Almeida, Inclusão Digital do Professor: formação e prática pedagógica. São Paulo: Editora Articulação, 2004.

[5] M. E. B. Almeida and J. A. Valente, Tecnologias e currículo: Trajetórias convergentes ou divergentes? São Paulo: Paulus, 2011.

[6] L. Bacich, Metodologias ativas para uma educação inovadora: uma abordagem teórico-prática. Porto Alegre: Penso, 2018.

[7] I. lacob, Perceções das crianças sobre as novas tecnologias na aprendizagem. Lisboa: Instituto Universitário de Lisboa, 2016.

[8] R. Brito, 'As TIC no Jardim-de-Infância: práticas de Educadores de Infância e crianças portuguesas', in Atas da CISTI 2010, 5a Conferência Ibérica de Sistemas e Tecnologias de Informação (pp.264-268). Santiago de Compostela: AISTI (Associação Ibérica de Sistemas e Tecnologias de Informação), Universidad de Santiago de Compostela. ISBN, Rocha, Ed. 2010.

[9] L. M. Gordor, 'A Study of Teacher Perceptions of Instructional Technology Integration in the Classroom', Delta Pi Epsil. J., vol. L, no. 2, pp. 63-76, 2008.

[10] V. Folho, G. Santos, and C. Abar, 'Tecnologias da Informação e Comunicação Aplicadas aos Processos de Ensino e de Aprendizagem: percepção de um grupo focal de professores de uma escola do Maranhão', Abakós, vol. 5, no. 2, pp. 3-15, 2017.

[11] M. Rub, 'Teachers' beliefs and technology use in kindergarten and elementary classrooms', World J. Educ. Technol., vol. 7, no. 3, pp. 149-156, 2015, doi: 10.18844/wjet.v7i3.202.

[12] A. Oliveira and R. Dias, 'Entre a Tentação e a Educação - Crescendo com os Mundos Virtuais', Biosofia, vol. 5, pp. 4 - 9, 2014.

[13] D. Laranjeiro, M. Antunes, and P. Santos, 'As tecnologias digitais na aprendizagem das crianças e no envolvimento parental no Jardim de Infância: Estudo exploratório das necessidades das educadoras de infância', Rev. Port. Educ., vol. 30, no. 2, pp. 223-248, 2017, doi: 10.21814/rpe.9367.

[14] R. Santos et al., "GET-UP" study rationale and protocol: a cluster randomised controlled trial to evaluate the effects of reduced sitting on toddlers' cognitive development', BMC Pediatr., vol. 16, Nov. 2016, doi: 10.1186/s12887-016-0723-6.

[15] D. Palak and R. T. Walls, 'Teachers' Beliefs and Technology Practices: A Mixed-methods Approach', J. Res. Technol. Educ., vol. 41, no. 4, pp. 417-441, 2009.

[16] J. Bergmann and A. Sams, Sala de aula invertida: uma metodologia ativa de aprendizagem. Rio de Janeiro: LTC, 2017.

[17] C. Ribeiro, A. C. Loureiro, C. Mesquita, and R. P. Lopes, 'O impacto do COVID-19 em educação pré-escolar: análise das estratégias desenvolvidas', presented at the INNODOCT2020 INNODOCT/18. International Conference on Innovation, Documentation and Education, Valencia, Spain, 2020.

[18] M. Meirinhos and A. J. Osório, Práticas educativas com TIC: uma proposta de ação. Revista de Estudios e Investigación en Psicologia y Educación. 2015.

[19] A. Loureiro, C. Cavalcanti, and C. Tavares, 'Concepções docentes sobre o uso das tecnologias na educação', Renote Rev. Novas Tecnol. Na Educ., vol. 17, pp. 468-477, 2019, doi: 10.22456/1679-1916.99530.

[20] R. P. Lopes, C. Mesquita, A. Durán-Sánchez, and J. R. Coca, 'The Ethical Assumptions in Higher Education', in Technological Progress, Inequality and Entrepreneurship, V. Ratten, Ed. Cham: Springer International Publishing, 2020, pp. 87-105.

[21] P. Bourdieu, Outline of a Theory of Practice. Cambridge: Cambridge University Press, 1977.

[22] G. D. Kamberelis, G., and W. A, 'Focus group research and/in figured worlds', in The SAGE handbook of qualitative research, N. Denzin and Y. Lincoln, Eds. California, US: SAGE Publications, Inc, 2005, pp. 1202- 1239.

[23] L. Bardin, Análise de Conteúdo. Edições 70, 2015. 
[24] J. Vala, 'Representações sociais e percepções intergrupais', Análise Social, vol. 140, no. 1, pp. 729, 1997. 